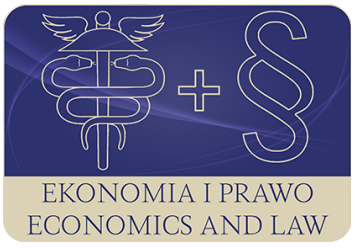

EKONOMIA I PRAWO. ECONOMICS AND LAW

\author{
Volume 20, Issue 3, September 2021
}

p-ISSN 1898-2255, e-ISSN 2392-1625

www.economicsandlaw.pl

EKONOMIA I PRAWO
ECONOMICS AND LAW

ORIGINAL ARTICLE

received 24.02.2021; revised 10.09.2021; accepted 30.09.2021

Citation: Grzega, U. (2021). Sustainable consumption in macroeconomic approach in Poland.

Ekonomia i Prawo. Economics and Law, 20(3), 529-541. https://doi.org/10.12775/EiP.2021.032.

\title{
Sustainable consumption in macroeconomic approach in Poland
}

\author{
URSZULA GRZEGA \\ University of Economics in Katowice, College of Management, Department of Consumption \\ Research, ul. 1 Maja 50, 40-287 Katowice, Poland \\ ๑ugrzega@ue.katowice.pl \\ D orcid.org/0000-0002-1220-7880
}

\begin{abstract}
Motivation: The studies on sustainable consumption are conducted in Poland and worldwide on the basis of various source data. Macroeconomic perspective is one of research approaches. The data obtained from the system of national accounts are especially important for the assessment of the situation in Poland. As a result of research specific indicators are obtained which express changes in various areas of functioning of consumption entities in the perspective of sustainable consumption.

Aim: to indicate the main trends of research on sustainable consumption in macroeconomic approach in Poland and to recognise the changes in the area of sustainable consumption on the basis of indicators adopted in the research on sustainable development conducted by Central Statistical Office.

Results: In Polish official statistics, the process of tracing sustainable development which includes sustainable consumption as an integral part, can be conducted with the use of the set of indicators monitoring four main orders, i.e. social, economic, environmental and institutional, as well as political order. Indicators related to the patterns of sustainable consumption are located in the group of indicators of social order and include such measures as the structure of average monthly expenditure per capita in households by type, the structure of passenger cars by age groups and electricity consumption in households per capita. Conducted research shows that in the years 2004-2019 favourable changes were reported in Poland in the structure of individual consumption in the household sector. They were related to the decrease in the value of the food index and the increase in the expenditures free choice indicator. At the same time, the data from Central Statistical Office shows that a regression was observed in the other two research areas, i.e. the structure of passenger cars by age and energy consumption in households.
\end{abstract}


Keywords: sustainable consumption; sustainable consumption indicators; sustainable economic development; Poland

JEL: E21; Q01

\section{Introduction}

Excessive pursuit of free market liberalism has brought enormous environmental, social and moral damages to societies (Khan, 2015, p. 15). The scale of the resulting damages made the measures used before to assess economic and social progress become increasingly less useful. From the point of view of new challenges of the surroundings of the end of the 20th and the beginning of the 21st century, they did not fulfil the measuring functions. The last 25 years have been a period of significant growth of researchers' interest in the issues of sustainable development, i.e. development free from excessive social, environmental and other costs. Consumption as an integral part of sustainable development should constitute a sustainable path to prosperity (Caeiro at al., 2012, p. 78). However, its level is continuously increasing every year. Consumption of many consumer goods, as well as the number of used and then disposed products is growing in terms of quantity and value. This translates into the problem of environmental pollution and depletion of natural resources, among others, which cannot be balanced by the benefits resulting from product and technological innovations. Therefore, it is becoming important to promote and spread ideas and practices of sustainable consumption, which represents the optimal, conscious and responsible use of available natural resources, goods and services at the level of individual consumers, households, territorial communities and entire societies, in accordance with the principles of sustainable development. It seems equally important to develop appropriate measurement tools, which by nature is complicated, delayed and often indirect.

The goal of the considerations is to indicate the main trends of research on sustainable consumption in macroeconomic approach in Poland and to recognise the changes in the area of sustainable consumption on the basis of indicators adopted in the research on sustainable development conducted by Central Statistical Office.

\section{Literature review: the measurement of sustainable consumption in macro approach, general assumptions}

According to the definition, sustainable consumption refers to the process of using goods and services that meets people's basic needs and brings better quality of life at simultaneous reduction of consumption of natural resources, toxic materials, and the emission of waste and pollution throughout the whole product life cycle in the way that does not compromise the ability of future generations to meet their own needs (Jaros, 2016, p. 25). It is one of the first definitions of sustainable consumption developed in Oslo in 1994. 
Nowadays, sustainable consumption can be perceived in a narrower and broader sense. In the narrower sense, sustainable consumption refers to more efficient and effective consumption associated with reducing resource consumption, waste and pollution. A broader approach to the concept is connected with better quality of life, including improved health condition at simultaneous reduction in the use of environmental resources. Holistic definition of sustainable consumption comprises three main goals, i.e. reduction of total resource consumption, their fair distribution and achievement of well-being and appropriate quality of life (Jaros, 2014, p. 170).

These definitions reflect the significance of social, environmental and economic challenges. The issues of improving the quality of life, intergenerational equality, and meeting the needs perceived as conventionally necessary in the appropriate way are of crucial importance. These concepts are a part of sustainable consumption (Bartolj at al., 2018, p. 35). Considering various aspects of the above definitions, it can be stated that sustainable consumption refers to deliberate, responsibility-based consumption that is a result of reasonable impact of various entities observed on the supply and demand side and operating on a micro and macro-economic scale. Sustainable consumption represents, among others the use of alternative items of consumption coming from secondary markets, that use renewable raw materials, energy-saving devices, and innovative ways of meeting needs. Sustainable consumption also refers to a lower level of consumption and consumption taking into account the interests of other entities, including future generations and natural environmental conditions. An important part, or actually the goal of sustainable consumption, is to improve the quality of life of the population in total and entire societies with special focus on the privileged groups (Grzega, 2020, p. 67).

Many indicators of sustainable development and sustainable consumption have been developed over the past twenty five years. Their comprehensive overview can be found, among others in such publications: Engelbrecht (2014), Murovec et al. (2016), Schoenaker et al. (2015). Some of them show relative sustainability in terms of various aspects that fall within the area of sustainable development (e.g. Happy Planet index, sustainable competitiveness index or the index sustainable consumption in households), while others focus mainly on one selected aspect. Some indices of sustainable development implicitly include consumption through the use of consumption indicators (e.g. resources). However, there are still no appropriate composite measures for the research on sustainable development that would allow international comparisons over time, which would refer not only to the economic aspect but also environmental and social.

The studies on sustainable consumption are conducted in Poland and worldwide on the basis of various source data. Macroeconomic perspective, which is used to describe the situation on the basis of macroeconomic data is one of research approaches. Considering this, it should be emphasized that the data obtained from the system of national accounts (published in Central Statistical 
Office) are especially important for the assessment of the situation in Poland. As a result of measuring sustainable consumption, specific numbers are obtained. They can take the form of measures or indicators. They express changes in various areas of functioning of economy and consumption entities in time and space. These measurements concern events, objects and phenomena, which makes them complicated and multifaceted (Kieżel \& Grzega, 2018, p. 90).

When starting considerations concerning the measurement of sustainable consumption in Poland, it should be emphasized that they currently result from the general guidelines of the European Union in the area of sustainable consumption and production, i.e. objective 12 of Agenda 2030, which is the result of the provisions adopted on 25 September 2015 by the General Assembly of the United Nations. From the point of view of the evaluation of the sustainability of consumption, such issues as promoting sustainable purchasing practices, a pro-ecological lifestyle of consumers, development of new technologies and consumption methods recommended by scientists and other specialists are particularly important. It is specifically about the efficient use of resources, reducing the food consumption and post-consumer waste, as well as the safe disposal of toxic waste and pollution (Rada Ministrów RP, 2018, p. 67). Increasing the efficiency of the use of resources as well as changing the attitude to resources that consists in departing from their linear management but also changing the models of consumption, i.e. the development of the circular economy are the major priority in the area of sustainable consumption and production resulting from goal 12 (GUS, 2020b).

To assess the measurement of progress in achievement of the goal associated with responsible consumption and production, the EU adopts indicators clustered in three main groups: decoupling environmental impacts from economic growth, energy consumption and waste generation and management. These are indicators such as: consumption of toxic chemicals, resource productivity, average $\mathrm{CO}_{2}$ emissions per km from new passenger cars, energy productivity, primary energy consumption, final energy consumption, share of renewable energy in gross final energy consumption, circular material use rate, generation of waste excluding major mineral wastes, recycling rate of waste excluding major mineral waste (Eurostat, 2019, p. 234).

The set of monitoring indicators is to enable the assessment of progress in the implementation of individual goals of sustainable development of the 2030 Agenda. Thanks to a uniform set of measures, it is not only possible to compare individual countries, but also to present changes on a global scale. Nevertheless, it happens that this set is different from the set of indicators monitoring national priorities. And so, the Polish set of indicators was created to monitor the priorities of sustainable development in Poland, that were set at ministerial level and defined in the report entitled Implementation of the sustainable development goals in Poland: report 2018. Its essential part is made of the measures monitoring the Strategy for Responsible Development. This set differs in some areas from the global set, because according to the assumptions of the 2030 
Agenda, signatory countries can and even should take into account the assumptions of the national priorities of sustainable development, including national conditions and specificity of their own measurement indicators (GUS, 2020c).

It should be stated that data for Poland are not available for all indicators monitoring global goals, because we do not always have a properly developed and internationally agreed methodology on the basis of which indicators could be calculated. It also happens that in some cases, despite the availability of comparable data, a given indicator is not published and included in the measurement, because it is considered inadequate to monitor sustainable development in the context of Poland (e.g. some phenomena do not occur in our country or their occurrence is not important for the assessment of progress in the study of sustainable development). Certainly, while keeping public statistics, Central Statistical Office aims to ensure data for all indicators from the global list, which have established methodology, and are relevant in the context of monitoring of the situation in Poland. This often requires the effort of many public institutions in the sphere of determining the source of data, calculation of the value of indicators and their updating. The set of indicators monitoring goal 12 of sustainable development, i.e. responsible production and consumption, includes the so-called source analyses, published statistics and proxies. Published statistics represent indicators available for Poland.

Another proposal for indicators used in Polish official statistics to monitor progress in the sphere of sustainable development is presented in the publication entitled Sustainable development indicators for Poland 2015. It shows a set of measures in the system of four main orders, i.e. social, economic, environmental as well as institutional and political. The main assumptions and first works were started in 2009 and continued in two following years, during the implementation of the project entitled Support in the sphere of development of a set of indicators for monitoring national strategies of sustainable development: development and implementation of the Polish set of indicators of sustainable development. The result of the work was the first list of 76 indicators of sustainable development published in 2011 in the study entitled Sustainable development indicators for Poland. The conclusions from the analyses conducted on this basis were the starting point for further work, the result of which is an expanded list of indicators (GUS, 2015b, p. 3). Indicators related to the models of sustainable consumption are placed in the group of indicators of social order.

\section{Methods}

The aim of the research was to indicate the main trends of research on sustainable consumption in macroeconomic approach in Poland and to recognise the changes in the area of sustainable consumption on the basis of indicators adopted in the research on sustainable development conducted by Central Statistical Office. The additional aim was determining the position of Poland among the European Union countries in the in the studied context. To meet the objec- 
tive set, information that came from secondary sources was used. A research method applied involved a descriptive analysis with some elements of a quantitative analysis.

Measures adopted in this research originate from Eurostat and Central Statistical Office databases and they include the following:

- structure of passenger cars by age groups;

- electricity consumption in households per capita;

- structure of average monthly expenditure per capita in households by type.

The indices used in the study make it possible to formulate synthetic opinions, make comparisons and assessments in analyses conducted in time and space cross-section. They are also used when the research objective is to determine the dynamics of changes in social development. Moreover, they allow for describing the structure of the investigated phenomenon and provide information on trends in the development of particular dimensions of sustainable consumption.

\section{Results: changes in sustainable consumption in Poland}

The first indicator, i.e. the structure of passenger cars by age, shows the share of the number of passenger cars by specific age groups in the total number of passenger cars. This indicator is applied instead of the previously used vehicle density. Data concerning vehicles registered as of December 31, have been presented since 2009 according to the Central Register of Vehicles and Drivers. As regards the significance of the indicator of the vehicle structure for the models of sustainable consumption, it should be emphasised that vehicles have a negative impact on the environment, including pollution, noise, waste and absorption of huge amount of energy. The Central Statistical Office data shows that over the last several years, intensive development of mass motorization has been reported in Poland. The number of registered passenger cars at the end of 2019 reached 24.4 million and was by $41 \%$ higher than in 2010 (GUS, 2020d, p. 55). In the context of the impact of road transport on the situation and quality of the environment as well as road safety, the age of the vehicle, which is related to its technical condition, is especially important. Data in Table 1 shows that in December 2017 the largest number of registered passenger cars were $16-20$ years old $(21.8 \%)$ and $21-30$ (20.8\%). Considering the oldest age range of cars, it can be noticed that over half of cars used in Poland (57\%) are 16 years old and older. In comparison with 2010, an unfavourable trend can be observed in this sphere.

In the discussed period, the growth of the share of old cars (aged 16 and more) by 13.9 percentage points was reported. However, the share of new cars (up to 5 years old) decreased by 0.9 percentage points. The share of cars $12-15$ years old decreased by 11.8 percentage points, and the share of cars $6-11$ years old was at a similar level. Cars aged 12 years and older accounted for almost $3 / 4$ (73.6\%) of all registered passenger cars in Poland in 2017. However, in the analysed pe- 
riod, a slight increase in the share of cars up to 2 years old was observed (5.2\% in 2017 in comparison with $4.4 \%$ in 2010).

The report of the European Automobile Manufacturers Association on the age of cars in the EU (excluding Bulgaria, Cyprus and Malta, but with Norway, Switzerland and the United Kingdom) shows that at the end of 2019, the average age of passenger cars in Europe was 11.5 years. In Poland - the average was 14.1 years. A similar result was recorded in Slovakia and Latvia (14) and Croatia (14.6). Lithuanians (16.8), Estonians (16.7), Romanians (16.5) and Greeks (16) drive much older cars. Germany, than France and Italy have the most new cars in Europe (Czechowska, 2021).

The increase in the number and share of old cars is the result of the prices of new cars and the availability of used cars imported to Poland from other countries. The price attractiveness of cars imported from abroad is determined by their advanced age and the fact that they are often crashed repairable vehicles. Certainly, it is difficult to assess positively the large-scale import of used cars. It poses threats of ecological nature and safety on Polish roads, which in turn translates into the level of satisfaction of health needs and people's lives among others. Yet, in general, the phenomenon of the increase in the number of passenger cars on roads, including the old ones, should be assessed negatively because it is in conflict with the idea of sustainable development.

Electricity consumption in households per capita is another indicator contained in the area of research on the models of sustainable consumption. It shows the quantitative electricity consumption by households per capita. Electricity consumption by households comprises the total use of electricity, including electricity used for heating as well as the operation of electrical appliances. Energy consumption and the availability of its reliable and affordable sources are one of the basic conditions for the functioning and development of economy. However, excessive energy consumption can put unnecessary pressure on the environment, including fossil fuel depletion. The data from Central Statistical Office show that since 2004 an increase in electricity consumption in households can be observed in Poland. It results from the increase in the household possessions and electrical devices they have. In 2004, electricity consumption per capita in households reached $2.4 \mathrm{GJ}$, in $2018-2.7 \mathrm{GJ}$, and it has not actually changed since 2010 (only in 2016 this value was 2.8 GJ) (GUS, 2015b, pp. 132-133; 2016, p. 152; 2017b, p. 152; 2018, pp. 18-19; 2019b, pp. 18-19; 2020a, pp. 18-19).

Final energy consumption in households per person measures how much energy is consumed in the household, excluding transport. The data is not temperature adjusted, so changes from year to year are partly due to the weather. The data in Chart 1 indicate that in 2004-2018 final energy consumption in households per capita in Poland increased by 3.9\%, and in the EU-27 decreased by $9.2 \%$ in the same period. The highest energy consumption in 2018 among the EU countries was recorded in Finland (1032), Luxembourg (822) 
and Denmark (767), respectively. The lowest - in Malta (192), followed by Portugal (280), Bulgaria (317) and Spain (321) (Eurostat, 202lb).

The increase in the value of the indicator caused by visible changes in consumers' lifestyles towards a comfortable and time-saving life, contributes to the persistence of "unsustainable trends" in energy consumption by households, which should be assessed negatively.

The third and the same time the last indicator of sustainable consumption adopted in comprehensive research on sustainable development by Central Statistical Office is the structure of average monthly expenditure per capita in households by type. It is an indicator that replaced the indicator of average vegetable consumption per capita in households applied in previous measurements. Its purpose is to show the structure of household spending. Changes in the structure of expenditure express changes in the standard of households' living. For example, reducing the share of spending on food at increase in real disposable income indicates an improvement in the standard of living of households, and in their wealth.

Data in Table 2 show that in the years 2004-2019 the share of spending on food in total expenditure declined by 4.8 percentage points. Decrease was also observed in the percentage of expenditure on housing and energy carriers (1.3 percentage points), alcoholic beverages and tobacco products (1.2 percentage points), communication (1.1 percentage point) and education (0.4). On the other hand, there was a an increase in the share of spending on transport (2.2), health (1.7), restaurants and hotels (1.6), furnishings (1.3), clothing and footwear $(0.4)$, recreation and culture $(0.2)$, as well as other expenditure on goods and services (by 1.4).

The greatest change showing the improvement in the standard of living of Poles in the years 2004-2019 was the decrease in the value of nutrition indicator, with a simultaneous increase in real disposable gross income in the household sector by as much as 65\% (GUS, 2021). Continuous decline in the value of the discussed measure indicates a gradual improvement in the wealth of the Polish society. Similar conclusions can be formulated on the basis of the free choice expenditure index. Spending on recreation and culture, restaurants and hotels, and so-called other expenditure on goods and services was also included in this group for the needs of this study. The level of free choice expenditure, which reflects the level of meeting higher needs, is different depending on the year of the analysis. However, in general, in the years 2004-2019 this indicator showed a growing trend in the entire household sector, in which the share of free choice expenditure increased from $22.1 \%$ to $25.3 \%$, i.e. by 3.2 percentage points.

In general, he structure of household final consumption expenditure in Poland is different from the overall consumption structure of EU households. First and foremost, food expenditure is much higher. The share of food expenditures in total EU expenditures equaled $13 \%$ in 2019. However, there are some countries which exceed this level and conversely. It is easy to notice that countries 
on the south and east of Europe exceed, for the EU-27, the mean share of food expenditures and non-alcoholic beverages. The highest share of food expenditures is noted in Romania (25.2\%), Lithuania (20.3\%) and Estonia (19.3\%), the lowest in Luxemburg (8.6\%) and Ireland (8.7\%). Polish — against the EU average - people also spend more on alcohol and tobacco, health, clothing and footwear and other consumer goods and services. They definitely spend less on restaurants and hotels, then housing, transport and communications, as well as recreation and culture. The most similar element of the consumption structure of the individual household sector of Poland and EU-27 is education (Eurostat, 2021a).

\section{Conclusion}

Proposals of indicators to be used in research into sustainable consumption and sustainable development are developed on global or Community level, for example by Eurostat, the United Nations Environment Program, the European Environment Agency and National Geographic in cooperation with GlobeScan and at national level. In the latter case, their purpose is to monitor political efforts and their progress towards national strategies of sustainable development. This group includes Poland among others.

In Polish official statistics, the process of tracing sustainable development which includes sustainable consumption as an integral part, can be conducted with the use of the set of indicators monitoring four main orders, i.e. social, economic, environmental and institutional, as well as political order. Indicators related to the patterns of sustainable consumption are located in the group of indicators of social order and include such measures as the structure of average monthly expenditure per capita in households by type, the structure of passenger cars by age groups and electricity consumption in households per capita. Conducted research shows that in the years 2004-2019 favourable changes were reported in Poland in the structure of individual consumption in the household sector. They were related to the decrease in the value of the nutritional indicators, a decline in the share of primary expenditure in the overall structure of spending (including housing, education, communication) and the increase in the share of expenditure on restaurants, hotels, furnishings, clothing and footwear. At the same time, the data from Central Statistical Office shows that a regression was observed in the other two research areas, i.e. the structure of passenger cars by age and energy consumption in households.

Bearing in mind that households influence the environment all day long, every day of the week and in the year, through making decisions concerning what goods and services to buy, how often to use them, what to do with post-consumer waste, where to live, how to commute to work, where to spend holidays, etc., the impact of their individual "everyday" decisions is small, but on a macroeconomic scale, in total, it translates into the scope, direction and the nature of sustainable development throughout the country. Therefore 
it is important for consumers to be aware of the possibilities and intensification of efforts for sustainable consumption in their own household, supported by appropriate educational and promotional activities of entities responsible for shaping consumption in the country.

\section{References}

Bartolj, T., Murovec, N., \& Slabe-Erker, R. (2018). Development of a Household Sustainable Consumption Index and its application to EU-28. Sustainable Development, 26(1), 34-50. https://doi.org/10.1002/sd.1689.

Caeiro, S., Ramos, T., \& Huisingh, D. (2012). Procedures and criteria to develop and evaluate household sustainable consumption indicators. Journal of Cleaner Production, 27, 72-91. https://doi.org/10.1016/j.jclepro.2011.12.026.

Czechowska, E. (2021). Wiek samochodów w Europie: jakna tleinnych krajów wypada Polska. Retrieved 17.11.2021 from https://www.auto-swiat.pl/wiadomosci/ aktualnosci/wiek-samochodow-w-europie-jak-wypada-polska/h9jy55p.

Engelbrecht, H. (2014). A comparison of macro-level sustainability indices for OECD countries: conceptual and measurement issues. Economic Papers: A Journal of Applied Economics and Policy, 33(2), 137-152. https://doi. org/10.1111/1759-3441.12073.

Eurostat. (2019). Sustainable development in the European Union: monitoring report on progress towards the SDGsin an EU context. https://doi.org/10.2785/44964.

Eurostat. (2021a). Final consumption expenditure of households, by consumption purpose. Retrieved 17.11.2021 from https: / /ec.europa.eu/eurostat/databrowser/ view/tec00134/default/table?lang=en.

Eurostat. (2021b). Final energy consumption in households per capita. Retrieved 17.11.2021 from https://ec.europa.eu/eurostat/databrowser/view/ sdg_07_20/default/table.

Grzega, U. (2020), Zrównoważenie konsumpcji w ujęciu makroekonomicznym. In S. Smyczek (Ed.), Zrównoważona konsumpcja w polskich gospodarstwach domowych: postawy, zachowania, determinant (pp. 66-96). Uniwersytet Ekonomiczny w Katowicach.

GUS. (2013; 2015a; 2017a; 2019a). Transport drogowy w Polsce. Retrieved 27.09.2020 from https://stat.gov.pl/obszary-tematyczne/transport-i-lacznosc/transport/transport-drogowy-w-polsce-w-latach2018-i-2019,6,6.html.

GUS. (2015b). Wskaźniki zrównoważonego rozwoju Polski 2015. Retrieved 27.09.2020 from https://stat.gov.pl/obszary-tematyczne/inne-opracowania/inne-opracowania-zbiorcze/wskazniki-zrownowazonego-rozwoju-polski-2015,5,2.html

GUS. (2016; 2017b; 2018; 2019b; 2020a). Energia. Retrieved 27.09.2020 from https://stat.gov.pl/obszary-tematyczne/srodowisko-energia/energia.

GUS. (2020b). Cel 12: odpowiedzialna konsumpcja i produkcja. Retrieved 27.09.2020 from http://sdg.gov.pl/statistics_nat/12-1-b. 
GUS. (2020c). Priorytety krajowe SDG. Retrieved 25.11.2021 from https://sdg. gov.pl/priorytet.

GUS. (2020d). Rocznik statystyczny RP 2020. Retrieved 27.09.2020 from https://stat.gov.pl/download/gfx/portalinformacyjny/pl/defaultaktualnosci/5515/2/20/1/rocznik_statystyczny_rzeczypospolitej_polskiej_2020_ korekta_30.09.2021.pdf.

GUS. (2021). Wskaźniki makroekonomiczne. Retrieved 17.11.2021 from https:// stat.gov.pl/wskazniki-makroekonomiczne.

Jaros, B. (2014). Pomiar zrównoważonej konsumpcji. Optimum: Studia Ekonomiczne, 3(69), 169-183. https://doi.org/10.15290/ose.2014.03.69.11.

Jaros, B. (2016). Bariery i pozytywne tendencje w rozwoju zrównoważonej konsumpcji w Polsce. Ekonomia i Środowisko, 2(57), 24-36.

Khan, M. (2015). Putting 'good society' ahead of the economy: overcoming neoliberalism's growth trap and its costly consequences. Sustainable Development, 23(1), 55-63. https://doi.org/10.1002/sd.1571.

Kieżel, E., \& Grzega, U. (2018). Wydatki konsumpcyjne polskich gospodarstw domowych jako miara rozwoju gospodarki. In K. Żyminkowska (Ed.), Nowe koncepcje w nauce o marketingu i rynkach (pp. 89-100). Uniwersytet Ekonomiczny w Katowicach.

Murovec, N., Slabe Erker, R., \& Bartolj, T. (2016). Rankings and comparisons of Slovenia by alternative development indices. IER Working Paper, 89, 1-22.

Rada Ministrów RP. (2018). Realizacja celów zrównowazonego rozwoju w Polsce. Retrieved 21.02.2021 from http://unic.un.org.pl/files/259/Polska_ VNR_20180615.pdf.

Schoenaker, N., Hoekstra, R., \& Smits, J. (2015). Comparison of measurement systems for sustainable development at the national level. Sustainable Development, 23(5), 285-300. https://doi.org/10.1002/sd.1585.

\section{Acknowledgements}

Author contributions: author has given an approval to the final version of the article.

Funding: this research was fully funded by the University of Economics in Katowice, Faculty of Management statutory sources. 


\section{Appendix}

Table 1.

Structure of passenger cars by age groups in \%, in the years 2010-2017; total passenger cars in a given year $=100$

\begin{tabular}{lccccccc}
\hline Year & up to 2 years & $3-5$ & $6-11$ & $12-15$ & $16-20$ & $21-30$ & 21 and above \\
\hline 2010 & 4.2 & 6.6 & 16.9 & 28.4 & 18.9 & 15.8 & 8.4 \\
2011 & 3.8 & 6.9 & 16.2 & 27.3 & 19.7 & 16.8 & 9.3 \\
2012 & 4.2 & 6.3 & 19.1 & 22.0 & 20.3 & 18.2 & 10.2 \\
2013 & 4.1 & 5.5 & 19.2 & 20.0 & 21.1 & 19.0 & 11.1 \\
2014 & 4.1 & 5.0 & 19.2 & 18.5 & 21.9 & 19.1 & 11.7 \\
2015 & 4.3 & 5.1 & 18.3 & 17.0 & 22.7 & 19.6 & 13.1 \\
2016 & 4.7 & 4.9 & 17.2 & 16.6 & 22.9 & 20.0 & 13.6 \\
2017 & 5.2 & 4.7 & 16.5 & 16.6 & 21.8 & 20.8 & 14.4 \\
\hline
\end{tabular}

Source: Own preparation based on GUS (2013, p. 114; 2015a, p. 116; 2017a, p. 116; 2019a, p.80).

Table 2.

The structure of the household final consumption expenditure in Poland in the years 2004, 2008, 2012, 2016, 2019 (in \% of total expenditure, current prices)

\begin{tabular}{|c|c|c|c|c|c|}
\hline Expenditures & 2004 & 2008 & 2012 & 2016 & 2019 \\
\hline food and non-alcoholic beverages & 21.1 & 19.9 & 19.5 & 17.1 & 16.3 \\
\hline alcoholic beverages, tobacco, narcotics & 7.1 & 7.4 & 8.0 & 5.8 & 5.9 \\
\hline clothing and footwear & 4.8 & 4.0 & 3.8 & 5.0 & 5.2 \\
\hline housing, water, electricity, gas and other fuels & 21.3 & 21.2 & 22.8 & 21.2 & 20.0 \\
\hline furnishings & 4.3 & 4.3 & 4.3 & 5.2 & 5.6 \\
\hline health & 4.2 & 3.9 & 4.0 & 5.6 & 5.9 \\
\hline transport & 10.5 & 11.7 & 10.9 & 12.0 & 12.7 \\
\hline communication & 3.2 & 3.1 & 3.0 & 2.4 & 2.1 \\
\hline recreation and culture & 8.0 & 7.6 & 7.7 & 7.9 & 8.2 \\
\hline education & 1.4 & 1.2 & 1.2 & 1.0 & 1.0 \\
\hline restaurants and hotels & 2.9 & 2.8 & 2.8 & 3.9 & 4.5 \\
\hline miscellaneous goods and services & 11.2 & 12.0 & 12.0 & 12.9 & 12.6 \\
\hline
\end{tabular}

Source: Own preparation based on GUS (2021). 


\section{Chart 1.}

Final energy consumption in households per capita in Poland, in the years 20042018 (in kg oil equivalent)

650

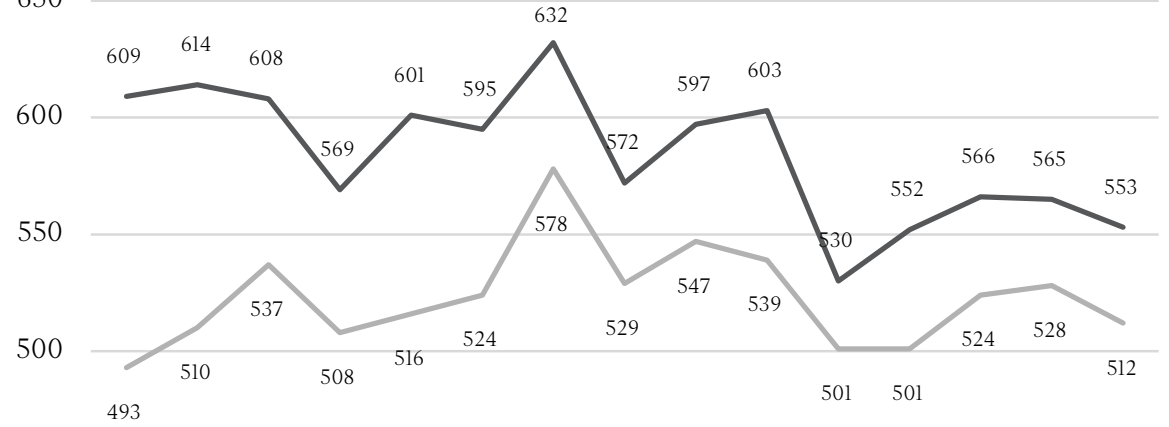

450

200420052006200720082009201020112012201320142015201620172018 Poland

EU-27

Source: Own preparation based on Eurostat (2021b). 
